\author{
Citation: Ülen M. \& Gülmez M., Six Sigma Approach To Improve Service Quality And A \\ Practice Study In Hospitality Sector, BMIJ, (2020), 8(3): 3150-3182, doi: \\ http://dx.doi.org/10.15295/bmij.v8i3.1555
}

\title{
SIX SIGMA APPROACH TO IMPROVE SERVICE QUALITY AND A PRACTICE STUDY IN HOSPITALITY SECTOR
}

\author{
Mesut ÜLEN ${ }^{1}$ \\ Mustafa GÜLMEZ 2
}

\author{
Received Date (Başvuru Tarihi): 28/06/2020 \\ Accepted Date (Kabul Tarihi): \\ $24 / 07 / 2020$ \\ Published Date (Yayın Tarihi): \\ $25 / 09 / 2020$
}

In the article, the first author is in the role of the Corresponding Author.

\begin{abstract}
Keywords:

Six Sigma,

Hospitality Sector,

Service Quality

JEL Codes:

L83,

$L 15$

Six Sigma is one of the latest quality improvement initiatives that have gained popularity and recognition in many sectors worldwide. It is expected that Six Sigma approach will also be adopted in the tourism sector, ensuring high service quality. This study aimed at applying a Six Sigma model to improve the service process of a five-star hotel located in the city centre. A total of 357 samples with sufficient data quality were taken from 386 questionnaire forms presented to the hotel customers. The data obtained were analyzed with Six Sigma methods and tools. The five steps, which are the expansion of DMAIC methodology, consisting of define, measure, analyze, improve and control, were followed from among these methods. The current situation of the hotel was defined in the first phase; sigma level about the service quality was calculated in measuring phase; the measurements were interpreted, and proposed solutions for the problems regarding improvement activities were presented in the analyzing phase; and lastly, controls to be carried out to ensure the continuity of these improvements were explained. One of the aims of the study is to examine with the Servqual model, whether there is a difference between the quality of service expected and perceived by customers who purchase services from an accommodation facility. A questionnaire based on the Servqual model, which consists of tangibles, reliability, empathy, responsiveness and assurance dimensions, was designed and used as a data collection tool. According to the results obtained, it was found that the expectations of the customers regarding hotel services in general, could not be met. The sigma score of the hotel was calculated as 2,01. In the study, tangibles and reliability dimensions were found to be the lowest level of satisfaction among hotel customers.
\end{abstract}

${ }^{1}$ Dr. Öğr. Gör., Akdeniz Üniversitesi, mulen@akdeniz.edu.tr,

2 Prof. Dr., Akdeniz Üniversitesi, mgulmez@akdeniz.edu.tr, https://orcid.org/0000-0003-3677-0472 https://orcid.org/0000-0002-2541-7377 


\section{HİZMET KALİTESININN İYİLEŞTİIILMESINNDE ALTI SİGMA YAKLAŞIMI VE KONAKLAMA SEKTÖRÜNDE BİR UYGULAMA}

$\ddot{O Z Z}$

Anahtar Kelimeler:

Altı Sigma,

Konaklama Sektörü,

Hizmet Kalitesi

JEL Kodlarn:

L83,

L15
Altı Sigma, dünya genelinde birçok sektörde popülerlik kazanmış ve kabul görmüş olan son kalite iyileştirme girişimlerindendir. Turizm sektöründe de Altı Sigma yaklaşımının benimsenerek, yüksek hizmet kalitesinin sağlanması beklenmektedir. Bu çalışma, şehir merkezinde bulunan beş yıldızlı bir otelin hizmet sürecini iyileştirmek için Altı Sigma modelini uygulamayı amaçlamaktadır. Otel müşterilerine sunulan 386 anket formundan veri kalitesi yeterli bulunan toplam 357 adet örneklem alınmıştır. Elde edilen veriler Altı Sigma yöntem ve araçlar ile analiz edilmiştir. Bu yöntemlerden tanımlama, ölçme, analiz, iyileştirme, kontrol'den oluşan TÖAİK metodolojisinin açılımı olan beş adım izlenmiştir. İlk adımda otelin mevcut durumu tanımlanmış, ölçme aşamasında hizmet kalitesine yönelik sigma seviyesi hesaplanmış, analiz aşamasında ise yapılan ölçümler yorumlanarak iyileştirme faaliyetlerine yönelik oteldeki aksaklıklarla ilgili çözüm önerileri sunulmuş ve son olarak yapılan bu iyileştirmelerin devamlılı̆̆ının sağlanması için yapılacak denetimler anlatılmıştır. Çalışmanın amaçlarından bir tanesi de, Servqual modeliyle bir konaklama işletmesinden hizmet satın alan müşterilerin bekledikleri ve algıladiklarn hizmet kalitesi arasındaki farklılık olup olmadığını incelemektir. Veri toplama aracı olarak fiziksel yeterlilik, güvenilirlik, empati, heveslilik ve güven boyutlarından oluşan Servqual modeline dayanan bir anket tasarlanmış ve kullanılmıştır. Elde edilen sonuçlara göre, genel olarak müşterilerin otel hizmetleri ile ilgili beklentilerinin karşılanamadığı görülmüştür. Otel işletmesine ait sigma skoru 2,01 olarak hesaplanmıştır. Çalışmada fiziksel yeterlilik ve güvenilirlik boyutlarının otel müşterileri arasında en düşük memnuniyet düzeyinde olduğu bulunmuştur. 


\section{INTRODUCTION}

Quality control and improvement activities play an essential role in all sectors of the economy. After traditional quality initiatives such as statistical quality control and total quality management, which have been important quality approaches for many years, Six Sigma is accepted as the last quality improvement initiative that has been popular and well-accepted in many sectors around the world (Chakrabarty and Tan, 2007: 194-195). To improve their operations and improve their performance, hotels around the world are actively focusing on a wide range of quality improvement initiatives such as Total Quality Management and Six Sigma. Currently, Six Sigma has replaced TQM to become one of the most successful process improvement systems (Kamar, 2014: 12).

The origin of Six Sigma comes from quality engineering traditionally based on robust statistical methods (Mast and Lokkerbol, 2012: 613). Much of the proven success of Six Sigma has been based on its implementation on production/manufacturing-like processes with little or no customer involvement. The Six Sigma approach, which was first applied in production activities, spread rapidly to different functional areas such as marketing, engineering and purchasing as the companies realized its benefits (Kwak and Anbari, 2006: 709). In the literature, there are many practices in which Six Sigma tool and methodology are used for services such as health services, call center and banking. In other services such as education and hotel management, Six Sigma is newly beginning to be applied (Noone et al., 2010: 274).

Six Sigma is not just about statistical tools and techniques. Service businesses do not need most of the Six Sigma tools and techniques (Antony et al., 2008: 12). Six Sigma is a business strategy used to increase business profitability and ensure excellence in service by applying both statistical and non-statistical tools. This excellence corresponds to 3,4 defects per million; that is, approximately 99.99966 success rate. Six Sigma is a project-oriented and statistical-based approach to reduce variability, rectify defects and eliminate waste stemming from products, processes and transactions (Montgomery and Woodall, 2008: 329). 
In Turkey, the incremental growth of hotels in the tourism sector in recent years offers more preferences to choose for consumers. The hospitality industry must continuously improve its activities to enhance the quality of goods and services and to develop competitive strategies and reduce operational costs. However, in the literature of our country, there are relatively scarce scientific studies of Six Sigma for the tourism sector. The reason why tourism companies keep away from Six Sigma is that they feel that because they are involved with a large amount of human workforce wherein witnessing any measurable defects is difficult (Bhale et al., 2017:2). Also, it is thought that in the future, as a theoretical framework, more research will be conducted with this methodology in the field of tourism, and researchers will be able to obtain different findings as a result of comparative analysis by applying similar studies in different enterprises in the tourism sector. Quality improvement studies, such as Six Sigma, which aims to increase the quality of accommodation services and customer satisfaction and reduce the variability in business processes, will contribute to both the industry and the literature.

In this study, the problems observed in the hotel were first introduced in defining phase within the framework of the DMAIC model. During the measuring phase, the sigma level was measured from the data obtained with the questionnaire study conducted to measure the levels of Servqual expectation and perception levels of the customers accommodating at the hotel, and the hypotheses created to determine the factors causing the defect were tested. In the analyzing phase, the causes of the problems were tried to be determined with the findings obtained from the customers in the previous phase. Finally, in the improvement and control phases, recommendations were made to enable continuous implementation of the control of the improvements as well as the improvement activities towards eliminating the problems by focusing on the problems causing nonconformity in the customer expectations. 


\section{LITERATURE REVIEW}

\subsection{The Concept and Definition of Six Sigma}

Pyzdek and Keller (2010) described quality as potential quality and actual quality, and they defined potential quality as the maximum possible value acquired per input and actual quality as the current value acquired per input. Six Sigma focuses on improving quality by reducing the difference (waste of quality) between potential and actual quality, helping organizations produce goods and services better, faster and cheaper (Pyzdek and Keller, 2010: 4). Six Sigma can be interpreted as a measure, a philosophy or a methodology in improving quality (Mitra, 2004: 294). Six Sigma programs draw their ideas from the Deming management philosophy, which is based on statistical thinking and statistical process control (Carley, 2014: 102).

Six Sigma is a system that tries to improve process consistency, reduce cycle time and increase productivity, eliminate faulty processes and defects and reduce overall costs in manufacturing or service environments (Noone et al., 2010: 275).

From a statistical perspective, Six Sigma is a quality improvement program that aims at reducing processes to the levels below 3,4 defects per million (Chakrabarty and Tan, 2007: 195) according to the characteristics of the goods or services. On the other hand, in terms of business perspective, Six Sigma is a business development strategy which tries to increase the efficiency and effectiveness of all processes that deal with customer needs and expectations (Antony and Banuelas, 2002: 21).

\subsection{Historical Development of Six Sigma}

In the 1970s, when the Japanese company took over Motorola's factory manufacturing Quasar televisions in the U.S., it made severe changes in the way the factory worked and soon started to produce television units with the same workforce, technology and design with a defect rate of $1 / 20$ of the defective manufacturing of former Motorola management (Pyzdek and Keller, 2010: 4). According to the plan made by Motorola's CEO Bob Galvin in 1987, the quality targets were achieved with 10 times improvement in two years, 100 times improvement in four years, and with reaching the Six Sigma qualification by the end of $5^{\text {th }}$ year (Gürsakal, 2005: 22). 
Six Sigma strategy, which started in the U.S. and Japan and spread all over the world, was first used in the 1995s in Turkey by TEI (Turkish Motor Industry) whose a significant amount of shares owned by G.E. company and then by a Turkish capital company, Arçelik (Bircan and Köse, 2012: 108). On the other hand, some of the manufacturing and service businesses continuing to use Six Sigma strategy in Turkey are as follows: Petrol Ofisi, BP, Shell, Ford, Aselsan, Eczacıbaşı, Bosch-Profilo, Borusan group, Tadım, Tuba, Kalekim, Finansbank, Hattat Holding, Hyundai Assan, ING bank, TAI, Teknosa, Zorlu energy group (Yüksel, 2008: 15). In the hospitality industry; Starwood Hotel \& Resort, which is the owner and operator of hotel brands such as Westin, Sheraton and many luxury and resort hotels, is one of the world's first hotel chains trying to adopt the Six Sigma philosophy (Lahap et al., 2017:3).

\subsection{The Importance of Six Sigma}

The main focus of Six Sigma philosophy is to find out how many defects exist in the processes; if this is revealed, it can be seen how to eliminate the defects systematically and as a result, perfection can be achieved. Firms are aiming to maintain competition around the world aim at the Six Sigma level, while traditional firms are content with three and four sigma ranges. This situation statistically corresponds to the range of 5 percent to 1 percent error rate (Öztürk, 2017: 205). Researchers have shown that most of the service processes such as payroll transactions, accounting, billing, shipping, order entry, response to service requests, baggage handling, etc. are carried out below 3,5 sigma quality level with a defect rate of over 23000 ppm or a success rate of 97,7 percentage (Y1lmaz and Chatterjee, 2000: 78).

If sigma quality level of any of the service mentioned above processes can be raised to four sigma quality level, the defect rate will drop significantly to $6210 \mathrm{ppm}$. Moreover, this demonstrates a 3.5-fold improvement in process performance. Service production efficiency will also increase to $99,38 \%$. Therefore, due to the reasons such as decreasing defect rate, decreasing customer complaints and increasing customer satisfaction, it will bring a significant financial return for the results of every institution dealing with robust business process development methodologies such as Six Sigma (Antony, 2006: 236). 
It is the ability to count defects in the process; in other words, knowing how many defects will be made when it is repeated a million times. Thus, the sigma level can be determined by calculating the success rate of the process. The relationship between process sigma levels and DPMO or PPM (Defects per Million Opportunities) is shown in Table 1.

Table 1. Sigma Conversion Table

\begin{tabular}{|c|c|c|}
\hline Success Rate (\%) & $\begin{array}{l}\text { Defects per Million } \\
\text { Opportunities (DPMO) }\end{array}$ & Sigma Level (o) \\
\hline 30,9 & 690000 & 1 \\
69,2 & 308000 & 2 \\
93,3 & 66800 & 3 \\
99,4 & 6210 & 5 \\
99,98 & 320 & 6 \\
99,99966 & 3,4 \\
\hline
\end{tabular}

Today, many organizations operate at approximately three or four Sigma levels, constantly losing customers due to loss of quality and are continuously lagging of the rival companies (Pande et al., 2012: 42). The defect rate of organizations operating at three or four Sigma levels is approximately in the range of 6.210 - 66.800 per million. If an organization moves the Sigma level from 3 Sigma to 4 Sigma, the number of defects per million will decrease in a way that varies from 66.800 to 6.210. If this organization increases its 4 Sigma level to 5 Sigma level, the defect rate per million will decrease from 6.210 up to 230. Six Sigma's vision is to reduce the defects in the processes by 3.4 per million probability, to ensure that the process works almost perfectly. In other words, Six Sigma predicts that the customer requirements will be met with a very close success rate of 99.9997\% (Bircan and Köse, 2012: 109). 


\subsection{Six Sigma in the Hospitality Sector}

The Six Sigma implementation in the hospitality industry is still in its beginning, as the examples of organizations in this industry that have successfully implemented these principles are relatively scarce (Cristina et al., 2018:385). One of the rare implementations in the literature, Kumar et al. (2009), in their study, applied the Six Sigma DMAIC model together with the Servqual Scale for the guests staying at the accommodation facility called Stout's Island Lodge in the USA and stated that the hotel reservation system should be reviewed. Personnel training investments should be given importance in order to prevent customer complaints. Senger, Ö. and Cengiz, Ö. (2018), applied the Six Sigma DMAIC model together with the Servqual Scale for the Hotel guests. The process chosen by Noone et al. (2010) for Six Sigma implementation was the check-in process of a chain hotel in the city center. Data regarding the number of defects in the check-in processes of the guests waiting in line to enter the hotel was collected and analyzed with the number of defects per million. In the survey studies on Six Sigma perception for 15 different hotel managers in the USA, Lee et al. (2012: 53-54) stated that important Six Sigma factors were management commitment, teamwork, communication, customer satisfaction and creativity factors; and the most useful features in the implementation of Six Sigma were customer satisfaction, efficiency, cost reduction and management commitment. In the creation of Table 2, the survey studies that followed the DMAIC steps in the hospitality sector were emphasized. 
Table 2. Six Sigma Implementations for the Hospitality Sector in the Literature

\begin{tabular}{|c|c|c|c|c|}
\hline References & Study Type/Place & Study Name & Data Source & $\begin{array}{c}\text { Tool/ } \\
\text { Method }\end{array}$ \\
\hline $\begin{array}{l}\text { Senger, Ö. and Cengiz, Ö. } \\
(2018)\end{array}$ & Article/Turkey & $\begin{array}{l}\text { Implementation Six Sigma of } \\
\text { Service Industry: A Case of } \\
\text { Tourism Industry }\end{array}$ & $\begin{array}{l}\text { Hotel } \\
\text { Customers } \\
\text { and staff }\end{array}$ & $\begin{array}{l}\text { Servqual } \\
\text { scale, } \\
\text { DMAIC }\end{array}$ \\
\hline $\begin{array}{l}\text { Lahap J., Bahri K. Johari,, } \\
\text { N., Zulkapli M., and Said } \\
\text { N }\end{array}$ & Article/ Malaysia & $\begin{array}{l}\text { Six Sigma and the Malaysian } \\
\text { Hotel Industry }\end{array}$ & Hotel Staff & $\begin{array}{l}\text { Survey } \\
\text { Study, } \\
\text { S.V. }\end{array}$ \\
\hline Kamar S.M. (2014) & Article / Egypt & $\begin{array}{l}\text { Six-Sigma Application in the } \\
\text { Hotel Industry: Is It Effective } \\
\text { for Performance Improvement }\end{array}$ & $\begin{array}{c}\text { Hotel } \\
\text { Managers }\end{array}$ & $\begin{array}{c}\text { Survey } \\
\text { Study for } 22 \\
\text { statements }\end{array}$ \\
\hline $\begin{array}{l}\text { Lee, B.B., Seo, W.S. and } \\
\text { Zhao, J. (2012) }\end{array}$ & Article / Korea & $\begin{array}{c}\text { Managers perception of six } \\
\text { sigma focused on hotels in the } \\
\text { U.S S }\end{array}$ & $\begin{array}{c}\text { Hotel } \\
\text { Managers }\end{array}$ & $\begin{array}{c}\text { Survey } \\
\text { Study for } 22 \\
\text { statements }\end{array}$ \\
\hline $\begin{array}{c}\text { Noone, B. M., } \\
\text { Namasivayam, K., and } \\
\text { Tomlinson, H. S. (2010) }\end{array}$ & Article & $\begin{array}{c}\text { Examining the application of } \\
\text { six sigma in the service } \\
\text { exchange }\end{array}$ & $\begin{array}{c}\text { Hotel } \\
\text { Customers }\end{array}$ & $\begin{array}{c}\text { Check-in } \\
\text { process } \\
\text { control map, } \\
\text { FMEA } \\
\end{array}$ \\
\hline Moralığlu, A. (2010) & Master/ Turkey & $\begin{array}{l}\text { Six Sigma in Service Sector } \\
\text { and Its Application in } \\
\text { Hospitality Industry }\end{array}$ & Hotel Staff & $\begin{array}{l}\text { Paretto, } \\
\text { FMEA }\end{array}$ \\
\hline $\begin{array}{c}\text { Kumar S.,Phillips A. and } \\
\text { Rupp J. (2009) }\end{array}$ & Article / USA & $\begin{array}{l}\text { Using Six Sigma DMAIC to } \\
\text { design a high-quality summer } \\
\text { lodge operation }\end{array}$ & $\begin{array}{l}\text { Hotel } \\
\text { Customers }\end{array}$ & $\begin{array}{l}\text { Servqual } \\
\text { scale, } \\
\text { DMAIC }\end{array}$ \\
\hline $\begin{array}{l}\text { Antony, J., and Kumar, M. } \\
(2008)\end{array}$ & $C$ & $\begin{array}{l}\text { Six Sigma in a Hotel Industry: } \\
\text { Some Preliminary } \\
\text { Observations and Agenda for } \\
\text { Future Research }\end{array}$ & Hotel Staff & $\begin{array}{l}\text { KBF Survey } \\
\text { Study }\end{array}$ \\
\hline Yüksel, G.(20 & Master/ & $\begin{array}{l}\text { Using the } 6 \text { Sigma Approach } \\
\text { in the Service Sector and Its } \\
\text { Applicability in Hospitality } \\
\text { Industry }\end{array}$ & $\begin{array}{l}\text { Six Sigma } \\
\text { processes } \\
\text { managed at } \\
\text { the hotel }\end{array}$ & $\begin{array}{c}\text { Process } \\
\text { maps, } \\
\text { FMEA, } \\
\text { Open-ended } \\
\text { questions }\end{array}$ \\
\hline Esenkal, F. (2006) & Master/ & $\begin{array}{c}\text { Six Sigma in quality } \\
\text { management and an } \\
\text { application trial in hotel } \\
\text { businesses }\end{array}$ & $\begin{array}{l}\text { Hotel } \\
\text { Customers } \\
\text { and Staff }\end{array}$ & $\begin{array}{l}\text { Servqual } \\
\text { scale, } \\
\text { DMAIC }\end{array}$ \\
\hline
\end{tabular}

\subsection{Service Quality}

In parallel with the developments in quality, the concept of service quality has recently become one of the most emphasized concepts, as well. Parasuraman et al. (1985: 42) 's service quality, which they define in terms of comparing service expectations with perceived service performances, shows the extent to which the service provided meets customer expectations. When the studies on service quality are examined in the literature, it is observed that various dimensions of service quality are 
emphasized. Parasuraman et al. (1988) 's study on general service quality is the most accepted and constitutes the basis for the implementations in the literature.

Parasuraman et al. (1988) reduced these dimensions to five. These dimensions are listed as follows;

1. Reliability: To be able to perform the promised service reliably and correctly.

2. Assurance: Knowledge, kindness and reliability of the personnel.

3. Responsiveness (to be able to respond): Willingness to help customers and fast service.

4. Tangibles: Appearance of the physical facility, equipment, personnel and contact material.

5. Empathy (to understand the customer): Striving to recognize customers and their needs.

Servqual offers a basic framework through expectations and perception, including descriptions for the five determinants of service quality. These studies formed the basis of the Servqual scale in measuring service quality. These dimensions constitute a template feature for a survey used as a measurement tool (Blesic et al. 2011: 7).

\subsection{Methods and Tools Used in Six Sigma Service Process Improvement}

Six Sigma benefits from many tools and methods that have proven useful to use for many years (project management tools, flow charts of processes, Pareto analysis, fishbone or cause-effect analysis diagrams and control charts, etc.) and it implements these with DMAIC approach in a simple performance improvement model known as Define, Measure, Analyze, Improve and Control (Noone et al., 2010: 276).

\subsubsection{DMAIC Model}

DMAIC referred to as the Six Sigma improvement plan, or the Six Sigma roadmap systematically examines how to define measure, improve, analyze and control the process to identify and eliminate the leading causes of nonconformity. As a problem-solving methodology or process improvement structure, Six Sigma strategy includes defining the problem (D), measuring the problem $(\mathrm{M})$, analyzing data to explore the root causes of the problem (A) (analysis of defects), improving (I) to 
eliminate the root causes of defects and controlling the processes (C) to prevent the perpetual problem or monitoring (Kumar et al., 2008:21). The DMAIC structure encourages creative thinking and solution to the problem within the process or service itself (Montgomery and Woodall, 2008: 335).

\subsubsection{Main Six Sigma Tools Used in Service Process Improvement}

Successful implementation of Six Sigma requires, even if they are not new, strict application of tools and techniques at different phases of the DMAIC model. One of the reasons why DMAIC is so successful is its focus on the effective use of statistical tools (Montgomery and Woodall, 2008: 335). Table 3 below provides several recommendations for the service industry regarding which tools and techniques should be used to improve service performance in Six Sigma practices and at what possible DMAIC phase will be used.

Table 3. Tools and Techniques Used in DMAIC Approach

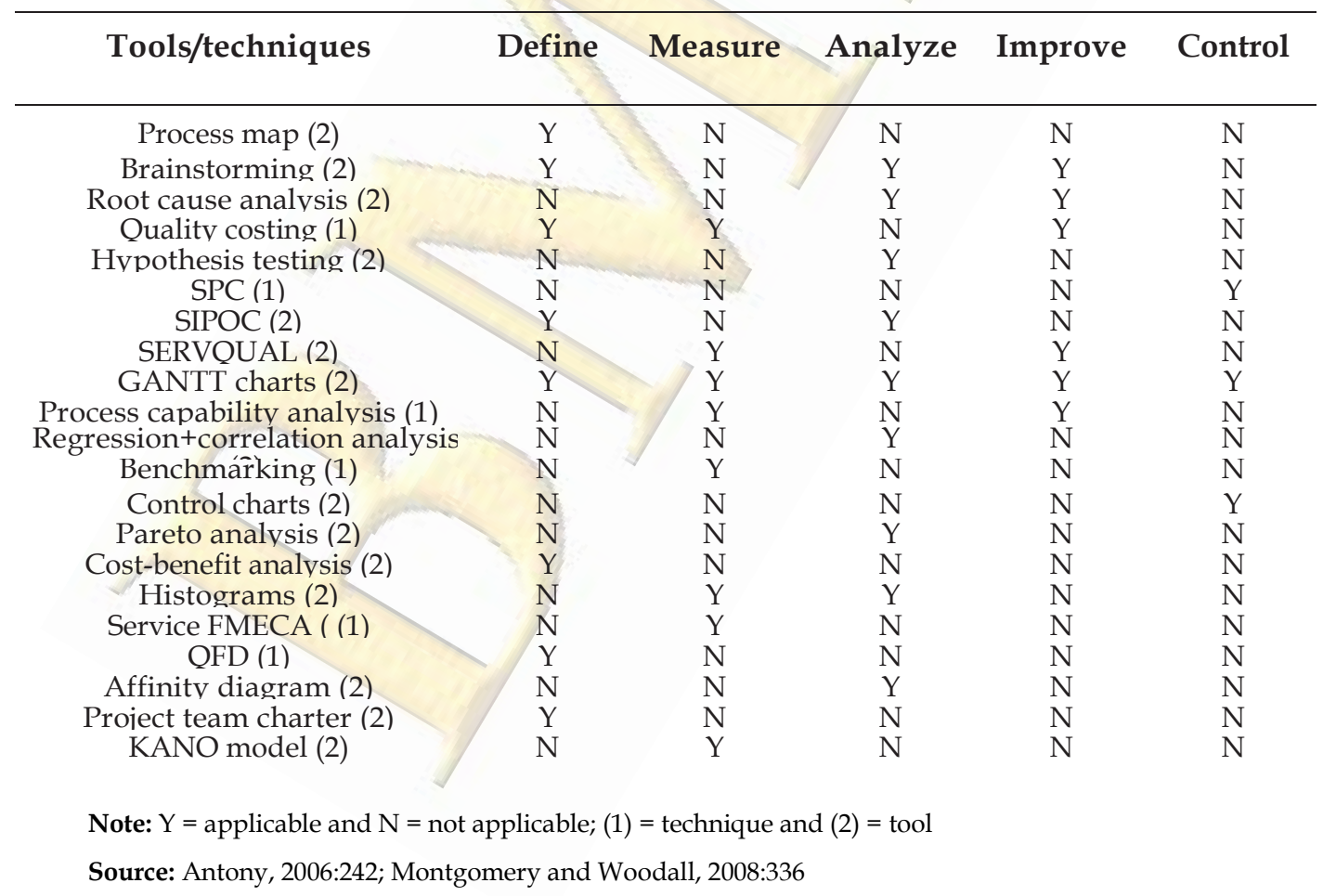

\section{RESULTS AND ANALYSIS}

This section will detail and analyze the application of Six Sigma for service process in the hotel. 


\subsection{Purpose and Importance of the Research}

In the service sector, it is becoming more challenging to meet the ever-changing needs of customers, to respond to their requests and to ensure customer satisfaction in an increasingly competitive environment. Within this environment, Six Sigma approach in the service sector has been adopted as a solution for continuous improvement in processes, providing customer satisfaction and corporate profit. This approach for reducing defects has had a significant impact on many service organizations.

In the study, it is aimed at increasing the service quality of the hotel by following the phases of the DMAIC model, which is a Six Sigma approach in the implementation of improving the service process quality. The sigma score of the hotel and the level of expectation of the service quality were compared, and the factors that caused the low quality were determined, and the necessary recommendations and suggestions were made to the facility.

Since Six Sigma is relatively new in the tourism industry, it is aimed at showing that Six Sigma is applicable and useful in such process environments.

\subsection{Research Method}

In the study, it is aimed at increasing the service quality of the hotel by following the phases of the DMAIC model, which has a Six Sigma approach in the implementation of improving the service process quality. The sigma score of the hotel and the level of expectation of the service quality were compared, and the factors that caused the low quality were determined, and the necessary recommendations and suggestions were made to the organization. Servqual Scale, which was applied to obtain information about the quality of service required for calculating the sigma level, was used. The data obtained through the questionnaire from the hotel was used to determine the factors causing low sigma level and quality problems with the hypotheses developed. In the study, t-test was applied to examine the scales according to two-stage sample variables. Paired t-test analysis was performed to determine whether expectation, perception of service and satisfaction scales were different. Variance analysis (ANOVA) was used to examine the relationship among 
expectation, service perception and satisfaction scales, and Sidak Paired Comparison Test was used to identify different sample groups. Chi-square analysis was applied to examine the relationships between the participants' satisfaction and dissatisfaction.

The scale used in this study was developed by Parasuraman, Zeithaml and Berry (1988) in the U.S. and the Servqual scale, which is widely used in service quality measurement, was used in the form adopted by Esenkal (2006:171). There is a Servqual scale with a total of 25 statements that measure service quality perception and expectations of the customers, which are used in service quality measurement and prepared according to the 5-point Likert scale. The questionnaire covers five dimensions of service quality (reliability, assurance, responsiveness, tangibles and empathy).

The study was carried out on the individuals who received service in different periods between 01.01.2018 and 31.12.2018 in a five-star city hotel in Antalya region. Therefore, there is no need for an ethics committee permission document in studies conducted with the data collected in the process before 2020. In the study, the convenience sampling method was used, and 386 participants were reached. In the study, 386 questionnaire forms were collected by considering different periods; however, the data of 29 participants whose data quality was not sufficient were not subjected to analysis. The analyses were conducted on 357 individuals who received accommodation service at the hotel.

In the survey study, Cronbach's Alpha coefficient was calculated in order to determine the level of Servqual expectations and perceived service quality of the participants and to test the reliability of 25 expressions. At the end of the analysis, Cronbach's Alpha coefficient was found to be 0.95 for the expectation level, and the perceived service quality scale reliability level was 0.96 . The obtained coefficient of a $\geq 0.9$ indicates that the scale is quite reliable. As a result, it was seen that there was no need to remove any questions from the study.

At the end of the factor analysis, five sub-dimensions were determined for the Expectation Scale. These dimensions are named as tangibles, reliability, assurance, responsiveness and empathy. KMO (sample adequacy coefficient) calculated in factor analysis was determined as 0.94 . This coefficient is an indication that 357 
questionnaires are sufficient to reveal the factor structure, besides, according to the Bartlet test result $(\mathrm{p}=0.01, \mathrm{p}<0.05)$ in which the significance of factor structures is tested, the dimensions obtained are structurally significant.

\subsection{DMAIC Model Implementation Phases}

\subsubsection{Defining Phase}

In defining phase, which is the first step of DMAIC approach, the Six Sigma practice to be done as mentioned in the meetings held with the hotel's general manager, marketing manager and guest relations manager in order to get full support of the top management and they were asked if they encountered with any problems. During the meetings, opinions were exchanged on issues such as service quality and efficiency, and information was obtained about the quality problems that caused customer dissatisfaction and indirect decrease in profitability of the hotel.

\subsubsection{Measuring Phase}

Two different versions of Servqual scale were used in this study to measure general expectations and expectation and perception levels of the customers. The questionnaire form consists of the Servqual scale, which contains 25 statements that measure service quality expectations and perceptions of the customers, which are used in the service quality measurement for the realization of Servqual Scale and prepared according to the 5-point Likert scale (very high 5, high 4, medium 3, low 2 and very low 1). Tangibles, reliability, assurance, responsiveness and empathy sub-dimensions take place in the expectations and perception levels regarding service quality dimensions.

In the hotel where the study was conducted, when the answers given by the customers in the questionnaire were collected and averaged, the values in Table 4 were found together with the perceived quality level parameters and the paired t-test by collecting the answers given for the column whose expectations levels were perceived in the same way. 
Table 4. Examining the Difference between General Servqual Service Quality SubDimensions

\begin{tabular}{|c|c|c|c|c|c|}
\hline Dimension & Satisfaction & $\bar{n}$ & $\bar{X}$ & S.s & $\bar{p}$ \\
\hline \multirow{2}{*}{ Reliability } & Expected & 357 & 3,90 & 0,57 & \multirow{2}{*}{$0,01^{*}$} \\
\hline & Perceived & 357 & 3,73 & 0,63 & \\
\hline \multirow{2}{*}{ Tangibles } & Expected & 357 & 3,89 & 0,60 & \multirow{2}{*}{$0,01^{*}$} \\
\hline & Perceived & 357 & 3,70 & 0,64 & \\
\hline \multirow{2}{*}{ Empathy } & Expected & 357 & 3,76 & 0,68 & \multirow{2}{*}{$0,01^{*}$} \\
\hline & Perceived & 357 & 3,63 & 0,65 & \\
\hline \multirow{2}{*}{ Responsiveness } & Expected & 357 & 3,94 & 0,66 & \multirow{2}{*}{0,45} \\
\hline & Perceived & 357 & 3,91 & 0,68 & \\
\hline \multirow{2}{*}{ Assurance } & Expected & 357 & 3,93 & 0,64 & \multirow{2}{*}{0,72} \\
\hline & Perceived & 357 & 3,95 & 0,74 & \\
\hline \multirow{2}{*}{ General } & Expected & 357 & 3,88 & 0,57 & \multirow{2}{*}{$0,01^{*}$} \\
\hline & Perceived & 357 & 3,78 & 0,59 & \\
\hline
\end{tabular}

It was determined that the general expected and perceived reliability, tangibles and empathy levels of the participants were significantly different $(p=0,01, p<0,05)$. It can be said that reason for the difference is that the Servqual scores related to the hotel where the customers accommodate are higher than the perceived Servqual scores from the expected reliability, tangibles and empathy levels as shown on Figure 1.

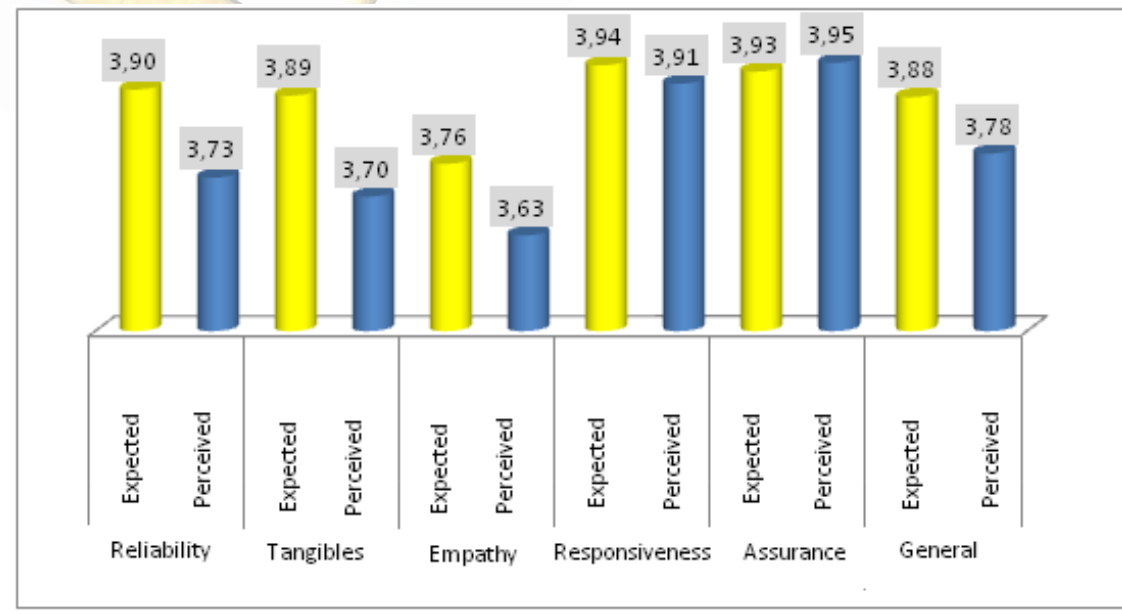

Figure 1. Difference Chart among Service Quality Sub-Dimensions 
Table 5. General Servqual Difference Service Quality Score

\begin{tabular}{lccccc}
\hline \multicolumn{1}{c}{ Score } & $\mathbf{n}$ & $\mathbf{X}$ & s.s & Minimum & Maximum \\
\hline General Servqual & 357 & $-0,10$ & 0,73 & $-2,56$ & 1,72 \\
Service Quality Score & & & & & \\
\hline
\end{tabular}

According to Table 5, the average of the customers overall Servqual service quality difference score is $-0.10 \pm 0.73$, the customer with the highest expectation is 1.72 , and the customer with the lowest expectation score is -2.56 . The average of the difference scores between expected and perceived quality levels calculated for each question statement is shown in Table 6 below. 
Table 6. Servqual Difference Scores by Item

\begin{tabular}{|c|c|c|c|c|c|}
\hline Statements & $\mathbf{n}$ & Minimum & Maximum & Average & S.S \\
\hline f1 & 357 & -4 & 4 & 0,01 & 1,00 \\
\hline f2 & 357 & -3 & 4 & $-0,01$ & 1,07 \\
\hline f3 & 357 & -4 & 2 & $-0,27$ & 0,91 \\
\hline $\mathrm{f} 4$ & 357 & -4 & 4 & $-0,26$ & 1,16 \\
\hline f5 & 357 & -3 & 3 & $-0,02$ & 1,10 \\
\hline f6 & 357 & -3 & 2 & $-0,27$ & 0,99 \\
\hline f7 & 357 & -4 & 3 & $-0,05$ & 1,12 \\
\hline f8 & 357 & -4 & 4 & $-0,04$ & 1,13 \\
\hline f9 & 357 & -4 & 3 & $-0,28$ & 1,17 \\
\hline f10 & 357 & -4 & 2 & $-0,41$ & 1,05 \\
\hline f11 & 357 & 0 & 2 & $-0,14$ & 0,96 \\
\hline f12 & 357 & -4 & 2 & $-0,14$ & 1,07 \\
\hline f13 & 357 & -4 & 4 & $-0,15$ & 1,28 \\
\hline f14 & 357 & -4 & 2 & $-0,20$ & 1,04 \\
\hline f15 & 357 & -4 & 2 & $-0,06$ & 1,12 \\
\hline f16 & 357 & -4 & 4 & 0,10 & 1,10 \\
\hline f17 & 357 & & 3 & $-0,43$ & 1,06 \\
\hline f18 & 357 & -4 & 4 & 0,08 & 1,10 \\
\hline f19 & 357 & -4 & 4 & 0,10 & 1,01 \\
\hline f20 & 357 & -4 & 3 & $-0,27$ & 0,97 \\
\hline f21 & 357 & -4 & 4 & 0,16 & 1,07 \\
\hline f22 & 357 & -4 & 4 & 0,07 & 1,12 \\
\hline f23 & 357 & -4 & 3 & $-0,24$ & 1,01 \\
\hline f24 & 357 & -4 & 4 & 0,04 & 1,11 \\
\hline f25 & 357 & -4 & 3 & $-0,01$ & 1,19 \\
\hline
\end{tabular}


Distribution of the defects caused by service quality servqual difference scores according to the criteria is shown in Table 7 in percentage.

Table 7. The Ratios of Defects Due to Difference Scores According to Quality Characteristics

\begin{tabular}{|c|c|}
\hline Criterion & $\begin{array}{c}\text { Defect } \\
\text { Percentage \% }\end{array}$ \\
\hline Tangibles & 37,84 \\
\hline Reliability & 30,46 \\
\hline Empathy & 16,30 \\
\hline Responsiveness & 8,92 \\
\hline Assurance & 6,46 \\
\hline
\end{tabular}

The Six Sigma philosophy deals with the number of defects observed in a process. On the other hand, the defects in the Servqual scale are adverse $(-1,-2,-3,-4)$ values, which consist of differences between perceived and expected values. 
Table 8. Average Number of Defects per Unit

\begin{tabular}{|c|c|c|c|}
\hline Statements & $\begin{array}{c}\text { Number of } \\
\text { Defects }\end{array}$ & Unit & $\begin{array}{c}\text { Number of } \\
\text { Defects per Unit }\end{array}$ \\
\hline The hotel is reliable & 81 & 357 & 0,22 \\
\hline Service is provided as promised & 97 & 357 & 0,27 \\
\hline $\begin{array}{l}\text { Records at the hotel (reservation, invoice, etc.) are kept } \\
\text { properly and accurately (without errors) }\end{array}$ & 126 & 357 & 0,35 \\
\hline $\begin{array}{l}\text { Tools and equipment in the hotel room (telephone, } \\
\text { television, air conditioner, etc.) work regularly and have } \\
\text { ease of use }\end{array}$ & 133 & 357 & 0,37 \\
\hline Service is provided swiftly & 99 & 357 & 0,27 \\
\hline Services are provided properly at the hotel & 130 & 357 & 0,36 \\
\hline $\begin{array}{l}\text { Requests and needs related to the hotel are provided on } \\
\text { time, accurately and completely }\end{array}$ & 105 & 357 & 0,29 \\
\hline Relevant complaints are heard and resolved & 106 & 357 & 0,29 \\
\hline Architectural structure of the hotel appeals to the eye & 128 & 357 & 0,35 \\
\hline Decoration of the hotel has quality furniture & 146 & 357 & 0,40 \\
\hline Illumination is sufficient in and around the hotel & 108 & 357 & 0,30 \\
\hline $\begin{array}{l}\text { Green areas around the hotel are regularly maintained } \\
\text { and protected }\end{array}$ & 107 & 357 & 0,29 \\
\hline Hotel's food and beverage menu is sufficient & 116 & 357 & 0,32 \\
\hline $\begin{array}{l}\text { Special days such as birthdays, wedding anniversary are } \\
\text { remembered }\end{array}$ & 116 & 357 & 0,32 \\
\hline $\begin{array}{l}\text { Staff have the necessary knowledge to answer customers } \\
\text { questions }\end{array}$ & 98 & 357 & 0,27 \\
\hline Staff arouses confidence in customers & 78 & 357 & 0,21 \\
\hline $\begin{array}{l}\text { Customers are provided with the necessary information } \\
\text { about the hotel's activities on time }\end{array}$ & 150 & 357 & 0,42 \\
\hline Staff is willing to serve & 79 & 357 & 0,22 \\
\hline $\begin{array}{l}\text { Physical appearance of the staff is clean and well- } \\
\text { groomed }\end{array}$ & 67 & 357 & 0,18 \\
\hline Staff is friendly and helpful & 142 & 357 & 0,39 \\
\hline Staff is polite and respectful towards customers & 63 & 357 & 0,17 \\
\hline $\begin{array}{l}\text { Staff is willing in the process of resolving possible } \\
\text { complaints }\end{array}$ & 83 & 357 & 0,23 \\
\hline $\begin{array}{l}\text { Staff does not create the impression that they want to get } \\
\text { shed of the customers when they ask questions }\end{array}$ & 134 & 357 & 0,37 \\
\hline Staff brings solutions to problems in teamwork & 97 & 357 & 0,27 \\
\hline Recommending the hotel to someone else & 97 & 357 & 0,27 \\
\hline & & Total & 7,52 \\
\hline \multicolumn{3}{|l|}{ Average number of defects per unit } & 0,30 \\
\hline
\end{tabular}


In the light of this information, with the average number of errors per unit we use sigma conversion table sigma intervals were found and sigma value was calculated as 2,01 with linear interpolation. The first part of the measuring phase was realized by determining the level of sigma. In the second part, the hypotheses were developed as specified below in order to understand the factors and defects that resulted from the Servqual Scale and causing low quality.

$\mathbf{H}_{1}$ : There is a difference in the perception levels of the service quality assessment of the hotel according to the ages of the customers.

$\mathbf{H}_{2}$ : There is a difference in the perception levels of the service quality assessment of the hotel according to the genders of the customers.

$\mathbf{H}_{3}$ : There is a difference in the perception levels of the service quality assessment of the hotel according to the marital status of the customers.

$\mathrm{H}_{4}$ : There is a difference in the perception levels of the service quality assessment of the hotel according to the educational status of the customers.

$\mathbf{H}_{5}$ : There is a difference in the perception levels of the service quality assessment of the hotel according to the monthly income levels of the customers.

$H_{6}$ : There is a difference in the perception levels of the service quality assessment of the hotel according to the purpose of the customers' arrival at the hotel.

$\mathbf{H}_{7}$ : There is a difference in the perception levels of the service quality assessment of the hotel according to the frequency of the customers coming to the city.

$\mathbf{H}_{8}$ : There is a difference in the perception levels of the service quality assessment of the hotel according to the way customers prefer the hotel.

In general, it has been determined that hotel customers do not have an impact on service quality dimension levels according to their gender, marital status, educational status, monthly income levels, the purpose of arrival to the hotel and frequency levels. In the study, the whole hypothesis 8 and the hypothesis of 1 as "There is a difference in the perception levels of the reliability dimension of the hotel according to the ages of the customers" were accepted. 


\subsubsection{Analyzing Phase}

In the analysis phase, the causes of nonconformities leading to low service quality were examined by using the findings revealed in the previous phase. For this purpose, during the questionnaire, the information obtained based on each question was combined, and the problems were identified.

Firstly, as seen in the measuring phase, it was found that the general expectation score of the customers was 3,88 and general perception score was 3,78. The reliability, tangibles and empathy Servqual scores of the customers were also found to be significantly different, as in general expected and perceived Servqual scores. Generally, it was seen that the expectations of the customers regarding the hotel services could not be met.

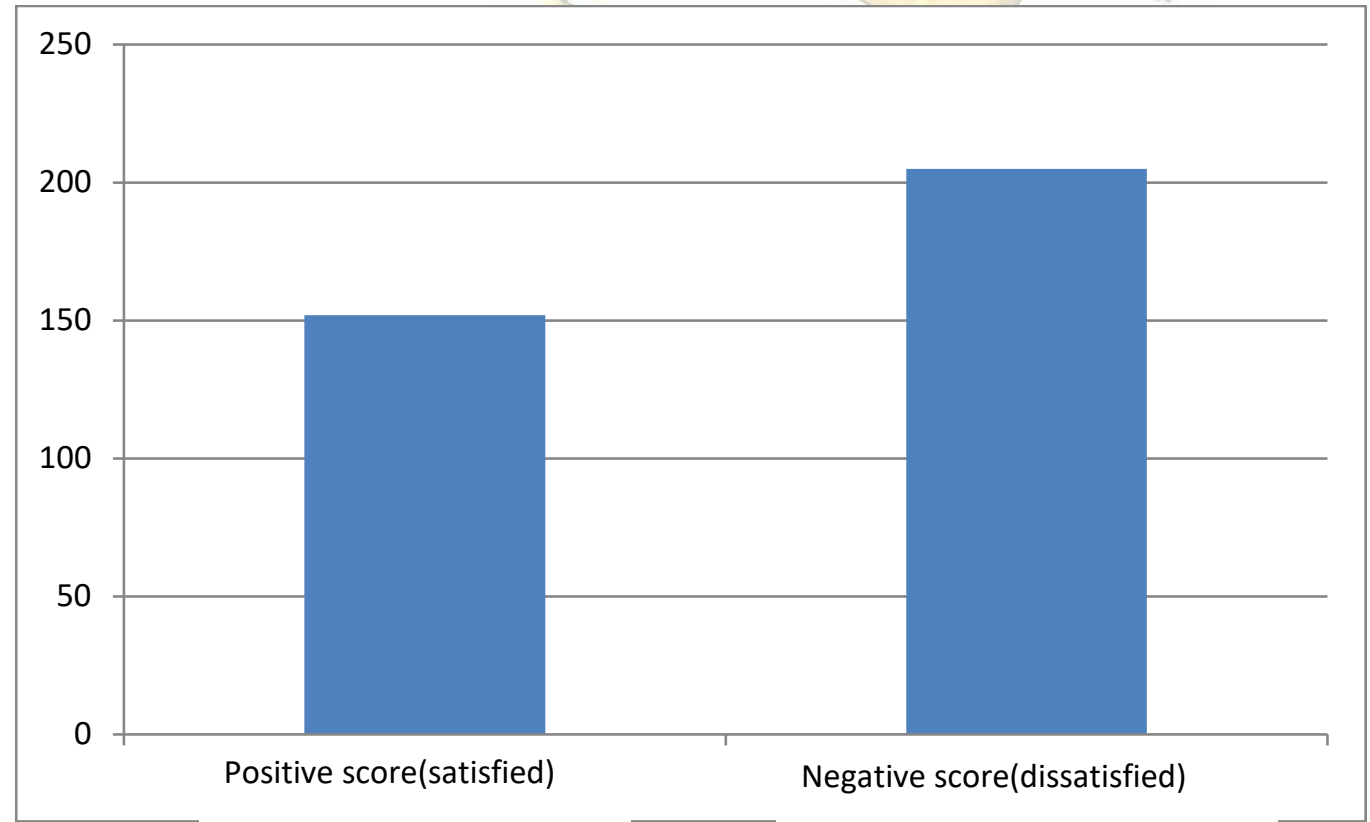

Figure 2. Group Chart by Difference Scores

According to Figure 2, in the differences of perception and expectation, the number of customers whose expectations were met sufficiently was found in accommodation service with $n=152$ and the number of customers whose satisfaction levels were low, and expectations were not met sufficiently was found as n=205 among 357 participants. It is seen that the group preferring the hotel by chance has a higher level of dissatisfaction $(13,2 \%)$ from the accommodation service, and the group that 
accommodates on recommendation has a higher level of satisfaction (34,9\%). Besides, it was found that the group consisting of the customers between the ages of 26-35 was more dissatisfied with the accommodation service (30,7\%).

In the questionnaire, which includes 25 statements in the measuring phase, the average values obtained by calculating the differences of expectations and perceptions for each question item are included. In Figure 3, the left part of the graph shows statements with negative averages, and the other side shows positive values. Statements in which the most negative difference was found in the data obtained from the answers given by the customers to the questionnaires were items 17 and 10, followed by items 9, 3, 5 and 20 in the ranking. On the other hand, according to the ranking in which the perceived quality was higher than expected, the difference was found to be positive in the questions with statements 21,18 and 22 .

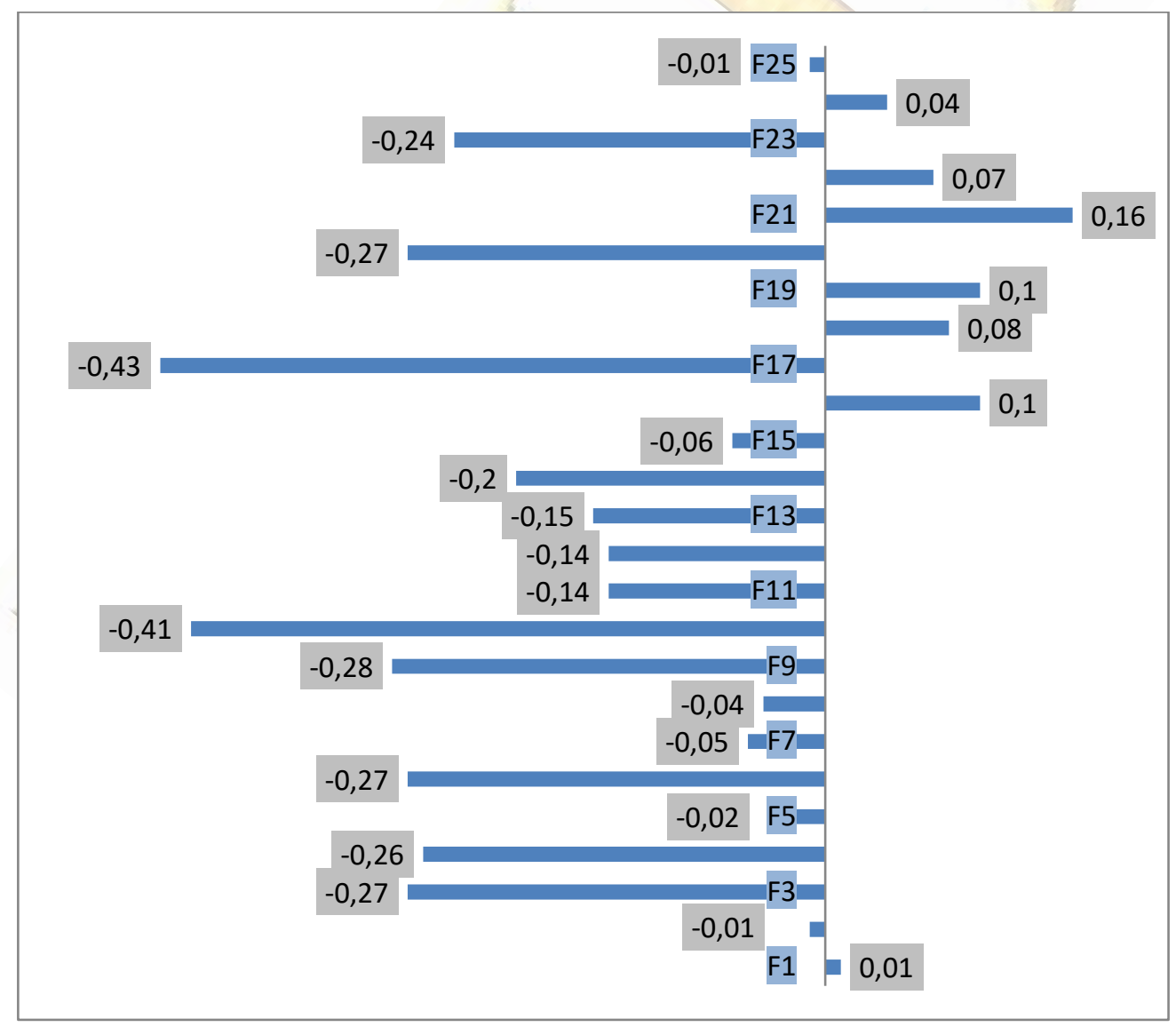

Figure 3. Difference Scores Chart Based on Statements

At the measuring phase earlier, in Table 5, along with the number of defects obtained from negative answers, the average number of defects per unit is used to 
determine the sigma level of the organization. For customers accommodating at the hotel, the defect value per million (ppm) was found as 300,952, and the sigma level was calculated as 2,01 . This low sigma score is in line with the negative difference between the overall expectation and perception scores that occur with Servqual Scale.

According to the questionnaires applied to the customers in the hotel, 37,84\% of the defects arise from tangibles, 30,46\% reliability, 16,30\% empathy, 8,92\% responsiveness and $6,46 \%$ assurance criteria. In the last part of the analyzing phase, the analyses of each quality criterion, which have been previously hypothesized and tested, are included.

\section{Tangibles}

The tangibles criterion of the hotel covers such a high rate as approximately $38 \%$ of the defects. Customer expectations could not be met in terms of the use of quality furniture in the decoration of the hotel, the architectural structure of the hotel and tools and equipment in the hotel rooms. Moreover, it was determined in the study that the accommodation preferences of the customers had an impact on the tangibles' levels. It was seen that tangibles levels of the customers accommodating upon advertisement, agency, by chance, internet, social media and other forms of preferences were lower than that of the customers accommodating on a recommendation.

\section{Reliability}

The hotel's reliability criterion covers approximately $31 \%$ of the defects. Customer expectations were not met on issues such as keeping the records accurately and adequately at the hotel, providing the services properly and giving the customer information about the hotel's activities on time.

In the study, it was determined that reliability levels of ages of the customers were different. Customers over the age of 26-35, 36-45, 46-55 and 56 were found to have lower levels of reliability than customers aged 18-25. In addition to founding to have, it was determined that customers accommodation preferences had an impact on their reliability levels. It was seen that reliability 
levels of the customers accommodating upon advertisement, agency, by chance, internet, social media and other forms of preferences were lower than that of the customers accommodating on a recommendation.

Empathy

The empathy criterion of the hotel covers about $16 \%$ of the defects. Expectations of the customers could not be met in such issues as the staff's not creating the impression that they wanted to get shed of the customers when they asked questions and remembering the special days.

In the study, it was determined that the accommodation preferences of the customers had an impact on their empathy levels. It was seen that the empathy levels of the customers accommodating upon social media and internet were higher than that of the customers accommodating upon by chance, agency and advertisement.

\section{Responsiveness}

The responsiveness criterion of the hotel covers about $9 \%$ of the defects. The expectations could not be met regarding the friendly and helpful staff and the swift service delivery. In the study, it was determined that the accommodation preferences of the customers had an impact on responsiveness levels. It was seen that the responsiveness levels of the customers accommodating upon recommendation, advertisement, agency and by chance were lower than that of the customers accommodating upon social media and the internet.

\section{Assurance}

The assurance criterion of the hotel covers approximately $6 \%$ of the defects. Expectations regarding the sufficiency of the hotel's food and beverage menu could not be met. In the study, it was determined that the accommodation preferences of the customers had an impact on their assurance levels. It was seen that the assurance levels of the customers accommodating upon by chance, agency and advertisement were higher than that of the customers accommodating upon social media and the internet. 


\subsubsection{Improving Phase}

So far, information has been obtained on all the factors that cause nonconformity in expectation levels in three phases. At this phase of the DMAIC methodology, according to the findings obtained from the analysis, it is aimed at increasing sigma level of the hotel by making various improvement and solution suggestions in the conclusion section. When determining the priority of the issues that can be improved at the hotel, it will be more appropriate to start with the criteria where expectations cannot be met, and problems are experienced the most. When a general evaluation of the problems in the hotel is made, the criteria such as tangibles, reliability and empathy are the most common problems.

Regarding the physical structure and equipment, there are deficiencies in the decoration of the hotel, such as the use of quality furniture, the architectural structure of the hotel and equipment in the hotel rooms. Before the customer enters the hotel building, the first thing to settle in their memories will be the exterior appearance of the building. Accordingly, the accommodation establishment should make sure that the desired hotel image is reflected on the target customers by revising all the visibility elements.

Although the building form is based on an architectural decision, exterior natural landscape works have become one of the popular methods in recent years. In addition to the use of quality furniture in the hotel's interior decoration, arrangements such as the use of interior illumination and plants will be solution recommendations that will create a more pleasant atmosphere in the hotel. Support can be obtained from specialist/professional companies for decoration in order to eliminate internal and external physical deficiencies.

The room allocated to the customer is the most important product of the hotel; the form and shape of the room are of critical importance for the customer. Ergonomic materials that care about aesthetics and respond to customer comfort should be included in the room equipment. Equipment that does not comply with these standards should be renewed. Also, some customers have stated the lack of available areas of use for the hotel, where requests and needs other than accommodation and eating/drinking can be met. In this regard, a relevant area of the hotel can be turned 
into a country garden by doing environmental planning research. The road to the beach, which is the only place where guests can spend time outside the hotel, is closed in the off-season, and therefore adversities occur. Ensuring that the gate opening to the beach remains open throughout the year is among the steps to be taken to achieve customer satisfaction. Customers may be more satisfied if they perceive that the staff is making an effort within the limits of the standardized process to meet their individual needs.

With the customer checking in to the hotel, the accommodation process begins. Thus, the registration of the customer is the beginning for the customer to accommodate in the hotel and at this stage, while providing general information about the facility, the necessary brochures or catalogues of the related activities should be presented to follow the activities such as animation and entertainment. Regarding this problem, in which the most frequent negativity is encountered, it should be ensured to prepare and hang notification banners which are prepared according to the content of activity programs on some boards in such places as hotel restaurant entrances, etc. One of the television channels in the hotel room can be allocated for these kinds of activities. In addition, activities targeting the customers aged 26-35 with the highest dissatisfaction rate should be carefully selected. Entertainment, show and concert programs that can be prepared for this age group can be planned.

Problems such as the reception queue and keeping the reservation information incorrectly as specified in the defining phase were also encountered during the analyzing phase. Some of the troubles experienced in the current reservation system are systemic, and some stems from the staff. This defect can be prevented by maintaining the customer information database. For example, in the Wyndham international customer-oriented strategy, when customers participate in the "Wyndham by Request" program, they complete a comprehensive profile, including general information, contact information and room preferences. The program guarantees the same level of personal service to its members regardless of their fast check-in/check-out preferences, personal interest (activities, magazines) areas and which Wyndham hotel they are checking-in. The hotel's 24-hour website should be activated and included in the existing reservation system. The fact that guests using 
the hotel's official website can check-in and check-out online can make the customer experience much more hassle-free. The membership system needs to be put into practice about creating loyal customers, and information such as birthdays, wedding anniversary, as well as general information of the members, will be recorded correctly.

Some hotels such as Marriott International, Hilton and MGM Resorts can generate a virtual room key through smartphone apps for their loyal customers. Customers can open the door via Bluetooth or barcode technology with their virtual key defined phones. These technologies, which will prevent unnecessary waste of time during the check-in and check-out processes, can be used with the activation of the hotel's smartphone application.

Customers can be more satisfied if they perceive that the staff is making efforts within the limits of the standardized service process to meet their individual needs. Concerning natural empathy, staff training is needed to deal with different guest types and needs in service quality. There is a staff circulation according to the workload which depends on the seasonal changes of tourism season in the hotel operating in the Mediterranean coastal region within the city. Furthermore, the pieces of training given to the employees who are recruited for seasonal and extra works are stuck in the workload and are inadequate. All these factors lead to delayed responses to customer requests from time to time. It is true that Six Sigma initially requires some investments to train the talented individuals in an organization and to form the team necessary for the implementation of the project; however, these investments will help employees maintain high service standards and consistency. In addition, Six Sigma tools can be used for the staff in future studies in order to increase efficiency in the organization and improve business processes.

After the improvements applied, the questionnaires directed to the customers are made again, and the improvement is controlled by comparing the change in sigma level with the initial data. If the customers fill in the questionnaires on the official website of the hotel via their mobile phones or online platform after checking out the hotel, the management will be able to make more conscious decisions, and the improvement and control activities will be perpetually applicable. 


\subsubsection{Controlling Phase}

The purpose of the controlling phase, which is the last step of the DMAIC method, is to ensure the sustainability of the improvements made. When the recommended improvement activities for the hotel's service processes are implemented, an increase in customer satisfaction will be achieved.

\section{CONCLUSION AND RECOMMENDATIONS}

In this challenging competitive environment, companies should create innovative goods and services that offer more experience in less time. As a strong business strategy, Six Sigma is seen as a must in order to achieve and maintain process and service-based perfection.

According to the general belief that prevails in service-oriented organizations such as the tourism industry, Six Sigma is seen as a solution tool for the production/manufacturing field because service processes are human-oriented and the defect to be measured is difficult to obtain. Its implementation in the service sector is minimal compared to other sectors due to various restrictions. The fact that service processes are structurally abstract makes it difficult to collect data, such as the necessity to establish a one-to-one relationship with customers in the collection of data. Measuring the quality of the service-oriented organizations and determining the sigma levels by finding the defects in the processes are relatively difficult compared to the production/manufacturing environment. The suitability and usability of data regarding quality constitute a restriction on Six Sigma's practices in the hotel industry. Resistance to change in a service-oriented environment can be an obstacle in the realization and control of improvements, largely due to the involvement of human behavioural features. Sharing advice and development reports in a language understood by the employees rather than a statistical language in the hotel will increase the motivation of the employees and their perceptions about the effectiveness of the Six Sigma business strategy.

In this study, following the literature review about Six Sigma, Six Sigma's DMAIC methodology was used to improve customer satisfaction by enhancing service quality in an accommodation establishment. With its roadmap, Six Sigma shows its 
difference by improving processes through measuring the current performance with statistical tools it uses in the DMAIC model and enabling the spread of this effect to the whole organization. The statistical data required at each phase of the DMAIC model built on the PDCA (plan-do-check-act) cycle are combined with scientific analysis and approaches.

The results of Six Sigma approach used in the research show that Six Sigma can solve problems and improve the process through DMAIC. The results of the research also show that the Servqual method applied in the Six Sigma methodology can be used to measure the quality of the services provided by the accommodation establishment. The quality of service is measured by comparing the two main factors, which consist of "perceptions" of the hotel customers for the service they receive and their "expectations" regarding the service they expect. The research results show that the five service quality dimensions, which are based on the Servqual method regarding tangibles, reliability, empathy, responsiveness and assurance, are capable of measuring the service quality of these five dimensions.

The sigma score of the hotel was calculated as 2,01 at the measuring phase of the study; this level, which corresponds to approximately $70 \%$ success rate, indicates 300.952 defects per million. This low sigma score shows similarity with the negative difference between customers general expectation scores of 3,88 and general perception scores of 3,78. According to the questionnaires applied to the customers in the hotel, $37,84 \%$ of the defects arise from tangibles, $30,46 \%$ reliability, $16,30 \%$ empathy, $8,92 \%$ responsiveness and 6,46\% assurance. The study found that tangibles and reliability dimensions were the lowest level of satisfaction among hotel customers. According to the results of the research, general service quality should be improved. Improvement of service quality should be initiated primarily from the tangibles dimension, which causes the most defects and has the highest gap value.

It has been seen that the only quality dimension where the expectations of the customers are met according to the dimensions is assurance. In terms of quality dimensions, it is understood that customers who receive hotel service give the highest importance to responsiveness and the lowest importance to empathy. 
Once the dimensions were examined according to demographic features, it was determined that the hotel customers did not have an impact on Servqual service quality dimensions according to their gender, marital status, educational status, monthly income levels, arrival purposes and frequency levels. When examined by age, it was determined that there was no difference for other dimensions except reliability. After the difference in reliability dimension was observed, it was seen that the difference was between 18-25 and 26-56 age groups. When the dissatisfied groups were examined, it was found that customers between the ages of 26-35 and those who preferred the hotel by chance showed higher dissatisfaction levels with the accommodation service. When the customers' preferences were analyzed, it was seen that the difference was significant for all dimensions. It was seen that tangibles and reliability levels of the customers accommodating upon the forms of preferences such as advertisement, agency, by chance, internet, social media were lower than that of the customers accommodating on the recommendation. The purpose of the Six Sigma strategy in the service process is to understand how defects occur and then develop process improvements to reduce the occurrence of such defects. Thus, customer satisfaction will be increased by improving the general customer experience.

Organizations applying Six Sigma can review any steps and numerical details in the processes of production of goods and services. Sigma scores, which are an indicator of service quality, can also be used as a comparison tool for accommodation companies aiming at increasing their value in the national and international area.

It is thought that in the future, as a theoretical framework, more researches will be carried out with this methodology in the field of tourism and researchers will be able to obtain different findings as a result of comparative analysis by applying similar studies in different service organizations in the tourism sector. 


\section{REFERENCES}

Antony, J. and Banuelas, R. (2002). "Key ingredients for the effective implementation of six sigma program". Measuring Business Excellence, (6)4: 20-7.

Antony, J. (2006)." Six sigma for service processes". Business Process Management,(12)2: 234-248.

Antony, J. and Kumar, M. (2008). Six Sigma in a Hotel Industry: Some Preliminary Observations and Agenda for Future Research. Jaakko Kujala ve Päivi Iskanius (Ed.). Proceedings of the 13th International Conference on Productivity and Quality Research ICPQR 2008: Productivity and Quality in Knowledge-based Organizations. University of Oulu, Department of Industrial Engineering and Management International Society of Productivit and Quality Research, s. 23-31, Oulu, Finland.

Aslan D. and Demir S. (2005). “Laboratuvar Tıbbında Altı Sigma Kalite Yönetimi”. Turk J Biochem, 30 (4): 272-278.

Bhale, N., Srividhya P., Marriappan V., Sony M. And Belokar V. (2017). "Six Sigma In Service: Insights From Hospitality Industry", 6 (2): 1-10.

Bircan, H. and Köse, S.(2012)."Altı Sigma ve Firmaların Altı Sigmaya Bakış Açısı: Sivas- Kayseri İli Örneği". Ekonomik ve Sosyal Araştırmalar Dergisi, 8(2): 107-129.

Blesic, I.,Ivkov, A., Stankov, U., Stamenkovic, I.ve Bradic, M. (2011). "Research of Expected and Perceived Service Quality in Hotel Management". Revista De Turism - Studii Si Cercetari in Turism, 0(11): 6-14.

Cengiz Ö. (2015). Altı Sigma Kalite Felsefesinin Hizmet Sektöründe Uygulanmast: Bir Turizm İşletmesi Örneği. Yüksek Lisans Tezi, Kafkas Üniversitesi, Sosyal Bilimler Enstitüsü, Kars.

Carley S. (2014). The Applicability of the Human Sigma Model to Service Quality Management in the U.K. Tourism Industry: an operational analysis, Doktora Tezi. University of Central Lancashire.

Chakrabarty A. and Tan C. (2007). "The current state of six sigma application in services". Managing Service Quality: An International Journal, (17)2: 194-208.

Cristina M., Olimpia S. And Daniel B. (2018). "Six Sigma Application for the Hotel Industry". New Trends in Sustainable Business and Consumption, p. 383-390, Heidelberg, Germany.

Esenkal, F. (2006). Kalite yönetiminde Altı Sigma ve otel işletmelerinde bir uygulama denemesi. Yüksek Lisans Tezi. Balıkesir Üniversitesi Sosyal Bilimler Enstitüsü, Balıkesir.

Gürsakal, N. (2005). Altı Sigma-Müşteri Odaklı Yönetim. Nobel Yayınları, Ankara.

Kamar S.M. (2014). "Six-Sigma Application in the Hotel Industry: Is It Effective for Performance Improvement?" Research Journal of Management Sciences, 3(12):1-14. 
Kwak, Y.H. and Anbari, F.T. (2006). "Benefits, obstacles and future of six sigma approach". Technovation, (26)5: 708-715.

Kumar, M., Antony, J., Madu, C.N., Montgomery, D.C. and Park, S.H. (2008). “Common myths of six sigma demystified". International Journal of Quality and Reliability Management, (25)8: 878-95.

Kumar S.,Phillips A. ve Rupp J. (2009). “Using Six Sigma DMAIC to design a high-quality summer lodge operation" Journal of Retail and Leisure Property, 8(3):173-191.

Lahap, J., Bahri, K., Johari,, N., Zulkapli M., and Said N. (2017). “Six Sigma and the Malaysian Hotel Industry". Journal of Tourism and Hospitality, 6 (6): 1-8.

Lee, B.B., Seo, W.S. and Zhao, J. (2012). “Managers' perception of six sigma focused on hotels in the U. S". Korea Academic Society of Hotel Administration, 21(1): 37-59.

Mast, J. and Lokkerbol, J. (2012). "An analysis of the Six Sigma DMAIC method from the perspective of problem solving". International Journal of Production Economics, 139(2): 604-614.

Mitra, A. (2004). “Six Sigma education: a critical role for academia". TQM magazine, 16 (4): 293-302.

Montgomery, D. C. and Woodall, W. H. (2008). “An Overview of Six Sigma”. International Statistical Review, 76(3): 329-346.

Moralığlu, A. (2010). Hizmet İşletmelerinde Altı Sigma ve Otelcilik Sektöründe Uygulaması. Yüksek Lisans Tezi. Dokuz Eylül Üniversitesi Sosyal Bilimler Enstitüsü, İzmir.

Noone, B. M., Namasivayam, K., and Tomlinson, H. S. (2010). “Examining the application of six sigma in the service exchange". Managing Service Quality. 20(3): 273-293.

Öztürk, İ. (2017). “Altı Sigma, Yalın Üretim ve Yalın Altı Sigma Metodolojisinin Tarımsal İşletmelerde Verimlilik ve Kalite Üzerine Etkisi”, KSÜ Doğa Bil. Dergisi., 20(3): 201-208.

Pande, S.P., Neuman, P. R. and Cavanagh, R. R. (2012). Six Sigma Yolu. (Çev. N.Güder ve G.Tokcan). Klan Yayınları, İstanbul.

Parasuraman, A., Zeithaml, V. A. ve Berry, L. L. (1985). “A Conceptual Model of Service Quality and Its Implications for Future Research". Journal of Marketing, (49)4: 41-50.

Parasuraman, A., Zeithaml, V. A. ve Berry, L. L. (1988). “Servqual: A Multiple- Item Scale for Measuring Consumer Perceptions of Service Quality". Journal of Retailing, 64(1):12-40.

Pyzdek, T. and Keller, P.A. (2010). The Six Sigma Handbook: A Complete Guide for Green Belts, Black Belts, and Managers at All Levels. McGraw-Hill, New York.

Senger, Ö. ve Cengiz, Ö. (2018). “Implementation Six Sigma of Service Industry: A Case of Tourism Industry". The Journal of Operations Research, Statistics, Econometrics and Management Information Systems, 6(1): 151-176. 
Yllmaz, M.R. and Chatterjee, S. (2000). "Six sigma beyond manufacturing- a concept for robust management". IEEE Engineering Management Review, (28)4: 73-80.

Yüksel, G.(2008). 6 Sigma Yaklaşımının Hizmet Sektöründe Kullanılması ve Konaklama İşletmelerinde Uygulanabilirliği. Yüksek Lisans Tezi, Anadolu Üniversitesi Sosyal Bilimler Enstitüsü, Eskişehir. 